Revista de BIOLOGía TROPICAL

\title{
Eulogy for Kristian Fauchald (1 July 1935 - 4 April 2015)
}

\author{
Sergio I. Salazar-Vallejo \\ Depto. Sistemática y Ecología Acuática, El Colegio de la Frontera Sur, Ave. Centenario km 5.5, Chetumal, México \\ (savs551216@hotmail.com, ssalazar@ecosur.mx)
}

Karen Osborn and Linda Ward launched an initiative to establish International Polychaete Day on 1st of July to celebrate Kristian's $80^{\text {th }}$ birthday. This took place in the National Museum of Natural History, Smithsonian Institution, Washington, DC, where he spent his last 35 years as an active researcher. This was a magnificent idea that will help remember him and to encourage the interest for studying polychaetes. The wish is that a similar celebration be done as well in many other institutions and countries.

According to GoogleScholar as of midAugust, 2015, Kristian had two papers with over 1000 citations; one is the "Diet of Worms" a compilation of polychaetes' feeding mechanisms, published with Peter Jumars (1793 citations), and the so-called Pink Book (1050 citations). The first one was selected as a CitationClassic when it had 245 citations and Kristian made an evaluation about it (Fauchald, 1992); there, despite the fact of its usefulness and high citation rate, he concluded: "Many of our conclusions ... are outdated. We were wrong, even spectacularly wrong sometimes." A few years before (Fauchald, 1989:748) he indicated that such synthesis "... was written as a summary of what little information was available in the 1970's and was intended to spur investigations." Just a few scientists dare to acknowledge their mistakes. Kristian was one of them; that was his intellectual stature. The relevance of the PinkBook is only possible by comparing its content with some other previous world-wide efforts. The first was

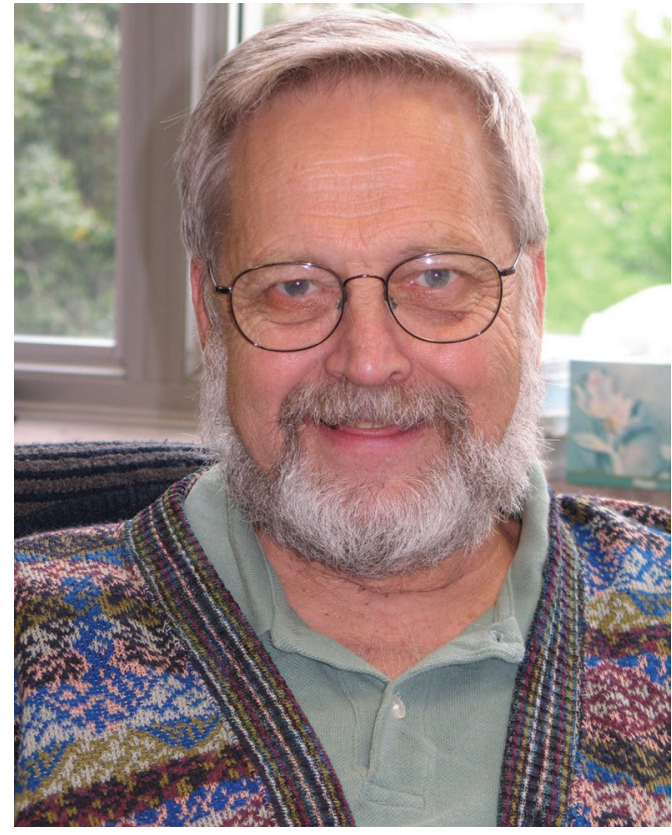

Kristian Fauchald, May 2005

made by Grube (1851) and included keys to 86 genera; Chamberlin (1919) made keys for 606 genera, and Fauchald (1977a) provided keys for 877 genera.

Some members of our academic community have written an obituary already and listed the 36 taxa named after Kristian including two genera and 34 species (Pleijel \& Rouse, 2015). Further, as part of the celebration for his 70th birthday there was an special issue in a prestigious journal which included two relevant contributions; one was a tribute (Rouse 
et al., 2005), and the other was a compilation of his publications and the taxa he proposed or described including three families, 34 genera, and 256 species (Ward, 2005).

For this eulogy I will combine some pleasant memories that changed my life, together with some details about his taxonomic philosophy which are apparently little understood or ignored. In both cases, I try to follow his path because Kristian did the same for his mentors: Olga Hartman (Fauchald \& Reish, 1977), and Carl Støp-Bowitz (Fauchald, 2000). Kristian's first publications were made with Hans Brattström, who was very influential in the development of marine biology in Chile as well (Bahamonde \& Báez, 2001), but it was Støp-Bowitz who offered some early guidance for his studies on polychaetes, and went to Los Angeles to work with Hartman for his Ph.D.

Kristian started working on nephtyid polychaetes and asked Hartman for some advice; in a letter dated March 13, 1964, he reflected on himself and his future and his thoughts deserve to be shared and understood for anyone seriously interested in science: "I do not consider myself a specialist on polychaetes in general, rather as a budding specialist on Nephtyids and nothing else... I think it is important for me now not to do too much damage to myself by publishing small and unimportant notes."

In 1979 Fernando Jiménez, a teacher in the Faculty of Biological Sciences, University of Nuevo León, gave me an important recommendation: "You must seek a training period or intensive course with a polychaete specialist; otherwise, your progress will be very slow and limited." I wrote to Marian Pettibone and to Kristian, who kindly suggested taking his polychaete summer course in Catalina Island. I arrived with a few ideas from invertebrate zoology textbooks but no practical experience with the polychaetes; I had a lab cloth and a rudimentary small forceps and one dissecting needle, but nothing else.

The course had two sections. The first two weeks there were two lectures and the remaining three weeks, we were supposed to work in our research project. Lectures were following the corresponding section by Pierre Fauvel in the Traite de Zoologie, and I was lucky I coud read French as well as English, albeit my spoken English was(is) terrible.

Lab sessions were very useful for me because I got used to terminology and keys in the Pink Book, and learnt about polychaete's morphology. I became too confident, too soon, because when I was unable to identify a lumbrinerid, I said aloud "Kristian, it seems that your key to genera of lumbrinerids is defective, because I cannot arrive to any genus with this worm." Kristian said: "That's interesting; let me take a look at it." He sat at my scope and said: "You're looking at the worm's posterior end; the key is for anterior regions."

I did learn as much as possible and enjoyed his guidance and patience with my frequent mistakes. If I tell that the course changed my life, that is to say very little, because I had no academic life before; I returned to Mexico full of enthusiasm and willing to make an academic career by studying polychaetes. This is why I owe Kristian most I have done on polychaetes; I was lucky enough to acknowledge this in public during his retirement party. Thanks again, Kristian.

By the way, Kristian recommended to focus on one or a few families such that I could have a deep understanding of the group; my reply and approach was the opposite because I felt that it was better to follow his achievement on Panamian polychaetes (Fauchald, 1977b), because he had dealt with all families.

I was wrong because I only grasp a shallow knowledge about the group; however, these mistakes had a positive effect because I could encourage some young colleagues that, like Ángel de León and Gerardo Góngora, managed to concentrate in a single family for their start, and one decade after we made the White Book of the Mexican polychaetes.

I was also lucky by meeting with Kristian more or less frequently, mostly in Washington but he visited Chetumal twice. During my sabbatical leave I was living with Len and him for three months, and this time allowed me to understand better why there was no simple 
questions regarding polychaete taxonomy: his replies were always pointing towards a research problem that deserved some attention, even if it seemed too distant from the current topic. Kristian made this not to overwhelm me, or others, but because by doing so, he emphasized the need to widen our own perspective and to improve our understanding of current research topics.

According to Wikipedia, "in philosophy, Eclectics use elements from multiple philosophies, texts, life experiences and their own philosophical ideas." On this ground, it is surprising that Kristian's synthesis about philosophy of biology and the study of polychaetes (Fauchald, 1989) has only 3 citations after GoogleScholar. His conclusions, and the need to improve the current scenario are far from being outdated. The main points are: a) most publications are descriptions of single or few species and type materials are rarely examined, b) most taxonomic groups have not been revised, and c) benthic ecological sampling is done with ill-defined objectives, and identifications of polychaetes are often wrong whenever done in a hurry.

Taxonomy entered the public and political agenda after the social concern about biodiversity's future. There were some specific, wishful recommendations and the Darwin Initiative and the NSF's PEET (Partnership for Enhancing Expertise in Taxonomy) programs were launched; however, the results fall behind expectations because funding was modest and some of the trainees failed to find a position as taxonomists (Agnarsson \& Kuntner, 2007; Rodman, 2007).

Beyond funding availability for new positions, there is a series of desirable practices for improving taxonomic studies of marine biodiversity; Kristian was involved in a series of considerations regarding the impact of fisheries (Vecchione et al. 2000), along two main issues: identifications and reliability. Among factors affecting the quality of identifications are the sources of information, the experience of identifiers, the difficulty for detecting some diagnostic features, ontogenetic changes, preservation quality of specimens, and presence of similar species. Some reasons for being suspicious include anomalous distributions, lack of reference or voucher materials, and improbable environmental conditions, what we have regarded as ecological horizon elsewhere (Salazar-Vallejo et al., 2014), for emphasizing that species could be present in similar conditions of temperature, salinity, substrate and depth.

Kristian also dealt with the taxonomic impediment (Fauchald, 2003). This implies the contrast bordering the need of information for bioconservation purposes, the high rate of landscape transformation, and the depressing condition of taxonomy. Thus, taxonomic impediment is due to the lack of taxonomic information, the many missing pieces of information, and the lack of adequate training programs in taxonomy. In this contribution Kristian gave some examples happening in the Smithsonian and emphasized the need for generating identification keys, taxonomic revisions, and phylogenetic analysis, together with a need to improve the quality of new species descriptions. This is a pending challenge. One hopes we can manage to follow his recommendations as the best means to honor his legacy and try to emulate his efforts.

\section{REFERENCES}

Agnarsson, I., \& Kuntner, M. (2007). Taxonomy in a changing world: Seeking solutions for a Science in crisis. Systematic Biology, 56, 531-539.

Bahamonde, N. \& Báez, P. (2001). Hans Brattström (19082000). Revista de Biología Marina y Oceanografia, 36, 123-127.

Chamberlin, R.V. (1919). The Annelida Polychaeta of the Albatross Tropical Pacific Expedition, 1891-1905. Memoirs of the Museum of Comparative Zoology, Harvard College, 48, 1-514.

Fauchald, K. (1977a). The polychaete worms: Definitions and keys to the orders, families and genera. Natural History Museum of Los Angeles County, Science Series, 28, 1-190.

Fauchald, K. (1977b). Polychaetes from intertidal areas in Panama, with a review of previous shallowwater records. Smithsonian Contributions to Zoology, $221,1-81$. 
Fauchald, K. (1989). The second annual Riser Lecture: Eclecticism and the study of polychaetes. Proceedings of the Biological Society of Washington, 102, 742-752.

Fauchald, K. (1992). Diet of worms. Current Contents, 40(8).

Fauchald, K. (2000). Carl Støp-Bowitz (1914-1997). Bulletin of Marine Science, 67, 10.

Fauchald, K. (2003). Taxonomic impediment in the study of marine invertebrates. In A. Legakis, S. Sfenthouakis, R. Polymeni, \& M. Thessalou-Legaski (Eds.), The New Panorama of Animal Evolution (pp. 637642). Proceedings of the $18^{\text {th }}$ International Congress of Zoology. Moscow: Pensoft Publishers. Retrieved from http://trove.nla.gov.au/work/15956044

Fauchald, K., \& Reish, D. J. (1977). Biography and bibliography of Dr. Olga Hartman. In D. J. Reish, \& K. Fauchald (Eds.). Essays on Polychaetous Annelids in Memory of Dr. Olga Hartman (pp. 1-23). Allan Hancock Foundation, University of Southern California, Los Angeles.

Grube, A. E. (1851). Uebersicht derAnnelidengattungen und Arten $\mathrm{zu}$ ihrer vorläufigen Unterscheidung. In Die Familien der Anneliden mit Angabe ihrer Gattungen und Arten (pp. 117-164). Berlin: Ein Systematischer Versuch. Nicolai'schen Buchhandlung.
Pleijel, F., \& Rouse, G. (2015). Obituary - Kristian Fauchald: WoRMS Polychaeta founding editor. http:// www.marinespecies.org/news.php? $\mathrm{p}=$ show\&id $=4152$

Rodman, J. E. (2007). Reflections on PEET, the Partnerships for Enhancing Expertise in Taxonomy. Zootaxa, $1668,41-46$.

Rouse, G., Gambi, M. C., \& Levin, L. A. (2005). Kristian Fauchald: A tribute. Marine Ecology, 26, 141-144.

Salazar-Vallejo, S. I., Carrera-Parra, L. F., González, N. E., \& Salazar-González, S. A. (2014). Biota portuaria y taxonomía. In A. M. Low-Pfeng, P. A. Quijón, \& E. M. Peters-Recagno (Eds.). Especies Invasoras Acuáticas: Casos de Estudio en Ecosistemas de México (pp. 33-54). SEMARNAT, INECC \& Univ. Prince Edward Island, México. Retrieved from www2. inecc.gob.mx/publicaciones/consultaPublicacion. html?id_pub=713

Vecchione, M., Mickevich, M. F., Fauchald, K., Collette, B. B., Williams, A. B., Munroe, T. A., \& Young, R. E. (2000). Importance of assessing taxonomic adequacy in determining fishing effects on marine biodiversity. ICES Journal of Marine Science, 57, 677-681.

Ward, L. (2005). The publications of Kristian Fauchald and the polychaete taxa named in those works. Marine Ecology, 26, 145-154. 